DOI: $10.2478 / \mathrm{v} 10025-007-0002-\mathrm{x}$

JOURNAL OF WATER

AND LAND DEVELOPMENT

J. Water Land Dev. No. 10, 2006: 15-38

\title{
Elements of water management planning according to EU Water Framework Directive in the catchment of Upper Narew
}

\author{
Dorota PUSŁOWSKA-TYSZEWSKA, Janusz KINDLER, \\ Sylwester TYSZEWSKI
}

Warsaw Technical University, Institute of Environmental Engineering Systems

\begin{abstract}
Analysis of the national and regional plans shows that the current year, 2006, shall determine the key lines of national and regional development practically till 2015, that means till the time when, under the Water Framework Directive, Poland should have achieved its major objectives. This year shall witness decision making not only on the key objectives, priority strategies and measures undertaken for social and economic development of the country and regions, but also allocation of the main streams of funds from the EU and public funds from national sources. This is a sort of challenge for administration bodies responsible for water management, particularly in respect of programming water management tasks and their incorporation into documents which are strategic for development on national and regional level. Over 2006-2008 efforts of water management administration bodies should be focused on incorporation of water management issues into the consecutive edition of the National Ecological Policy and environmental protection programmes - at regional level, to be followed by county and community levels. This paper is a part of the broad stream of methodology and pilot work on the implementation of provisions of the Water Framework Directive in Poland. The main body of the paper consists of the summary of work done for the pilot river basin of Upper Narew.
\end{abstract}

Key words: hydrology, management plan, river basin, water balance, water management

\section{INTRODUCTION}

The Water Framework Directive (WFD) requires the EU MS to undertake a number of measures leading to the achievement of good status of surface waters and groundwater. In order to achieve the WFD environmental objectives it is necessary to develop, by 2009, River Basin Management Plans. These plans shall also play the role of a reporting mechanism to the European Commission.

The major environmental objectives defined by the Water Framework Directive (Article 4), which are to be achieved by 2015 in river basin districts, are as follows: 
a) in respect of surface waters (inland, transitional and coastal waters):

- prevention of deterioration of water body status,

- achievement of good status by water bodies (exclusive of artificial and heavily modified water bodies),

- achievement of good ecological potential and good chemical status in artificial and heavily modified water bodies,

b) in respect of groundwaters:

- prevention or reduction of pollution discharge into groundwaters and prevention of deterioration of the status of all bodies of groundwater,

- achievement of good status of bodies of groundwater,

c) in respect of protected areas:

- achievement of a status which meets all standards and objectives laid down in the Community legal act, under which the given protected area was established.

In certain cases it is possible to extend the period for achievement of these objectives, and also to determine less rigorous objectives for certain water bodies (Article 4 , parts 4 and 5 of WFD).

This paper is a part of the broad stream of methodology and pilot work on the implementation of provisions of the Water Framework Directive in Poland. The main body of the paper consists of the summary of work done for the pilot river basin of Upper Narew. The work was carried out within the framework of PBZKBN 061/T07/2001 "Methodological Foundations of Integrated Water Management in Poland" grant, and was headed by Prof. E. Nachlik (2003-2005). Apart from discussing the work done for the pilot river basin, the paper also comprises methodological remarks on WFD defined planning process.

The first part of the paper discusses the major properties and stages of the planning process for water management planning in river basin districts, as recommended by the EU Water Framework Directive. This part takes into consideration the methodological remarks comprised in the paper "G3 Guidelines - Planning Water Management in Poland under the Provisions of the Water Framework Directive" (materials prepared within the framework of the PHARE PL/2002/000580.05.01 project "Technical Assistance in the Implementation of WFD 2000/60/EC in Poland", 2005).

A consecutive part of the paper is dedicated to methodological foundations of one of the most important stages of the planning process, namely identification of anthropogenic pressures on waters and their impact assessment. Such identification is an element of both the preliminary and the proper gap analysis within the river basin district and is a basis for implementation of further stages of the planning cycle, particularly development of RBMP, complete with a programme of measures required to achieve the WFD environmental objectives. A complete description of the methodology may be found in manual „Identyfikacja i ocena skutków antropogenicznych oddziaływań na zasoby wodne dla wskazania części wód zagrożonych 
nieosiagnięciem celów środowiskowych" (NACHLIK et al., 2004) [“Identification and Assessment of Anthropogenic Pressure Impacts on Water Resources for the Purpose of Indication to Water Bodies Threatened by Failing to Achieve Environmental Objectives"], developed within the framework of KBN grant mentioned earlier, which served as a basis for elaboration of this part of the paper and for the work done in the Upper Narew basin.

The consecutive chapter, which is the main part of the article, describes the sequence of tasks and the Authors' experience collected as a result of implementation of this methodology in the pilot Upper Narew basin. This chapter was prepared based on the monograph „Identyfikacja antropogenicznych oddziaływań na wody i ocena ich skutków na przykładzie zlewni Górnej Narwi" (PUSŁOWSKA et al., 2005) ["Identification of Anthropogenic Pressures on Waters and Assessment of their Impacts on the Example of Upper Narew Basin"]. It should be noted that the work in the pilot river basin has not yet included the water status forecast for 2015, nor analyses leading to determine measures required to achieve good water status by 2015. They were ended at the stage of assessment of the current status.

The last chapter is a summary consisting of two parts. The first part highlights the most essential problems and conditions associated with the process of development of River Basin Management Plans, the second part presents experience and major problems with implementation of the methodology in the pilot Upper Narew basin.

\section{WATER MANAGEMENT PLANNING UNDER THE WFD}

Introduction. Water management planning within a river basin is a continuous process, consisting of a number of components which are implemented in consecutive planning cycles in line with the schedule defined by the European Union Water Framework Directive (WFD). Planning tasks shall always be assisted by continuous effort towards verification, up-dating and expansion of the information base, and the new data and information should be used on a current basis for checking the correctness of earlier arrangements and introduction of essential corrections. The general flowchart of planning and implementation under the WFD is presented in Figure 1. The Figure presents individual components of the process for the first planning cycle foreseen for 2004-2009. The essential output of these actions shall consist in a programme of measures required to achieve the so-called good water status by 2015, that being the basic target of the WFD. Figure 1 also presents the first 6-year cycle of implementation of the measure programme over 2010-2015.

Measures taken to achieve good water status in the river basin districts shall be subordinated to the principles of integrated water management, which include integration of various objectives for those measures, various types of water 


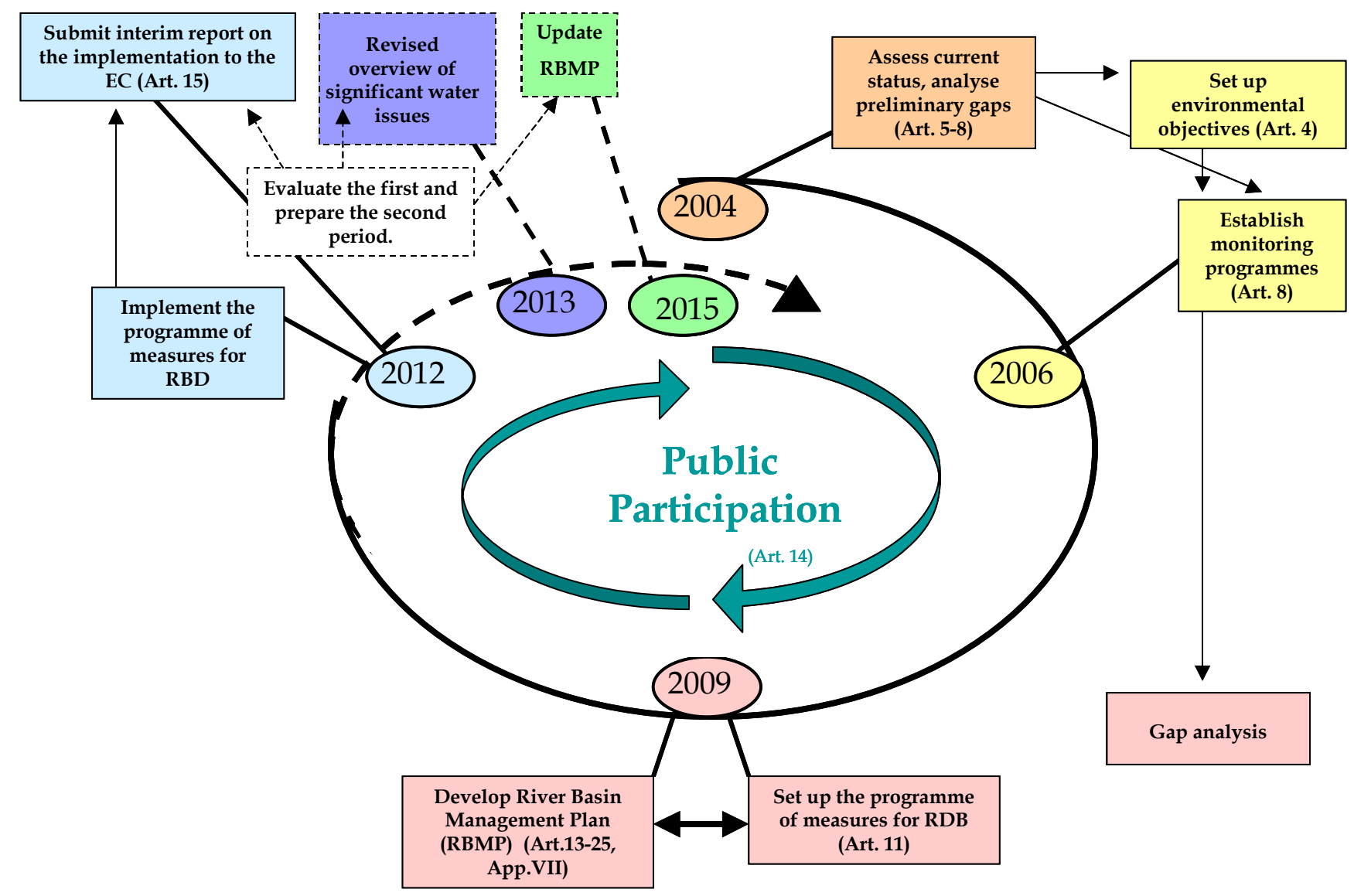

Fig. 1. Flowchart of the planning and implementation WFD (Best practices in river basin planning, Common Strategy on the Implementation of the Water Framework Directive, 2003) 
resources, integration of investment and non-investment projects, etc. Further integration of water policy is signalled in the draft new directive on measures for mitigation of flood hazards, published in January 2006 by the European Commission.

In all phases of the WFD planning process, MS shall ensure its coordination with any other planning tasks within RBD. In Poland it is particularly essential to coordinate work on water management planning within RBD with work on the Strategy for National Economic Development for 2007-2013, the regional development strategies and physical development plans, as well as plans for flood control and counteracting drought effects. In cases of international river basins institutions which develop water management plans for individual parts of the river basins need to cooperate.

In Poland, the Regional Water Management Authorities and the National Water Management Board (which shall be established in July 2006), which is to coordinate their activities, are the institutionally most appropriate platform for planning water management and its integration with other planning tasks executed on national scale in administrative units.

\section{COMPONENTS ON THE PLANNING PROCESS UNDER THE WFD}

The EC guidelines and the WFD define the following nine components of the water planning process:

1. Assessment of the current status and preliminary gaps analysis.

2. Setting up of the environmental objectives.

3. Establishment of monitoring programmes.

4. Gap analysis.

5. Setting up of the programme of measures.

6. Development of river basin management plans.

7/8. Implementation and evaluation of the programme of measures.

9. Information and public consultations.

Component 1. Assessment of the Current Status and Preliminary Gaps Analysis

Under the WFD provisions, assessment of the current status and preliminary gaps analysis require development of a river basin district characteristics, determination of surface water (rivers, lakes, transitional and coastal waters) and groundwater bodies, identification of major anthropogenic pressures and their impacts on the status of water resources as well as assessment of the level of risk of failing to meet the environmental status objectives in individual surface water and groundwater bodies, establishment of a protected areas register and preliminary economic analysis of water management.

In accordance with the WFD schedule, by the end of December 2004 Poland completed these tasks and in March 2006 the Ministry of Environment delivered the respective report to the European Commission. 
Component 2. Setting up of Environmental Objectives

The WFD lays down environmental objectives (Article 4) in respect of surface waters (inland, transitional and coastal), groundwater and protected areas. In this article derogations from meeting these requirements are allowed for specific cases. These derogations may relate to the time of meeting the requirements, adoption of less rigorous objectives, temporary deterioration of water status and consent to failure to meet the requirements due to undertaking new investments implemented in compliance with the principles of sustainable development. Setting up of objectives includes definition of ecological quality standards and determination of quality class limits for the required biological, physio-chemical and hydromorphological parameters, featuring the water status. It is also essential to assign specific requirements to individual water bodies, complete with fixing the deadlines for meeting these standards.

Component 3. Establishment of Monitoring Programmes

The major objective of monitoring consists in providing a cohesive and comprehensive description (review) of water status in river basin districts. Annex V to the directive presents types of monitoring programmes for surface waters and groundwaters, defines their objectives and formulates a number of recommendations for development of these programmes. Three types of monitoring programmes are envisaged: surveillance, operational and investigative.

The directive requires that monitoring programmes consistent with the WFD requirements be established by the end of 2006, both for surface waters and groundwaters. Commencement of implementation of the water status investigation programme should take place before the end of 2006. As of 2009 operational monitoring shall focus on assessment of effectiveness of the implemented programme of measures.

\section{Component 4. Gap Analysis}

Gap analysis is a substantial step between assessment of the current status and preliminary gap analysis (component 1) and development of programmes of measures (component 5). Its key objective consists in assessment of discrepancy between the status of water bodies (WB) and the requirements of good water status or good ecological potential (in respect of artificial or heavily modified water bodies). This assessment should be carried out both in respect of the current water status and in respect of the status forecast for 2015. This assessment shall be the basis for determination of economically justified measures allowing meeting the defined environmental objectives by 2015 .

Component 5. Setting up of the Programme of Measures

Under the WFD provisions, "each EU MS shall ensure development of a programme of measures for all river basin districts or parts of international river basin districts within their territory". The fundamental function of the programme of 
measures consists in achievement of the environmental objectives listed above. The WFD assumes that to achieve those objectives the programme of measures should comprise "primary" measures (ensuring implementation of Community regulations and national regulations) and "supplementary" measures, taken in situations where the "primary" measures are insufficient to achieve a goal.

Component 6. Development of River Basin Management Plans

The output of the planning process within a water basin district has the form of a water management plan which summarises the information and findings processed during the planning process components discussed above. The plan has to be published by December 22, 2009, and the publishing has to be preceded by presenting the plan for public consultation - not later than by December 22, 2008, which shall be followed by analysis of remarks made and possible correction of the plan. A 6-year RBMP up-dating cycle is envisaged (the first to take place in 2015).

Components $7 \& 8$. Implementation and Evaluation of the Programme of Measures

Implementation of the programme of measures must be combined with a continuous process of evaluation of its effectiveness. Such evaluations are considered a tool of permanent monitoring whether the planned measures bring the expected outputs, and in cases of any discrepancy with earlier forecasts, they are the basis for undertaking corrective action.

Upon completion of the first cycle of implementation of the programme of measures in 2015, observations made over 2012-2015 in respect of earlier planning work should provide valuable material for preparation of the next cycle of such work.

Component 9. Information and Public Consultations

The WFD requires that as broad as possible and general public participation is ensured during the water planning process.

Moreover, the provisions of Directive 2001/42/EC and the Environmental Law lay down a requirement of the development of a strategic environmental impact forecast for the draft river basin management plan and its public presentation under the EIA procedure.

\section{METHODOLOGY OF IDENTIFICATION OF ANTHROPOGENIC PRESSURES ON WATERS AND THEIR IMPACT ASSESSMENT}

The monograph "Identification of Anthropogenic Pressures on Waters and Assessment of their Impacts on the Example of Upper Narew Basin" (PUSŁOWSKATYSZEWSKA et al., 2005) was also published in 2005; it summarises the Authors' experience from implementation of methodology "Identification and Assessment of Anthropogenic Pressure Impacts on Water Resources for the Purpose of Indication 
to Water Bodies Threatened by Failing to Achieve Environmental Objectives" (NACHLIK et al., 2004) in the pilot Upper Narew basin. This publication is discussed in greater detail in Chapter 4 of this paper.

The process of analysis of anthropogenic pressures and their impacts is basically a process of assessment of the risk of failing to achieve the assumed objectives. It comes down to collection of available data on anthropogenic pressures in isolated water bodies, determination of the impact of these pressures on water status, assessment of the current water status and evaluation of capacity for achievement of environmental objectives assigned to them within the assumed timescale.

The review of pressures and their impacts on water status shall result in identification of those water bodies for which achievement of WFD environmental objectives is impossible or threatened, identification of the reasons for this situation and risk assessment.

In consecutive components of the planning process the results of the analysis of anthropogenic pressures on waters and their impacts shall be used for preliminary evaluation of the risk of failing to achieve the environmental objectives in the threatened water bodies and for development of a monitoring programme focused on verification of the causes of threat. Verified results of the analysis of pressures shall be used as a basis for determination of a programme of measures allowing the achievement of the assumed environmental objectives in the threatened water bodies. The monitoring programmes shall provide information required for verification of the evaluation of the risk of failing to achieve environmental objectives, determination of the status of water bodies and assessment of the effects of implementation of the programme of measures.

\section{Procedure for the Analysis of Pressures and their Impacts}

The procedure for carrying out the analysis of pressures and their impacts includes the following stages:

1. Development of numerical data bases, cooperating with GIS.

2. Characteristics of individual water bodies.

3. Assessment of the status of individual water bodies.

4. Identification of essential pressures based on detailed analysis.

5. Preliminary estimation of the risk of failing to achieve the environmental objectives - through formulation of conclusions and recommendations for individual water bodies.

Detailed discussion of individual stages of the above procedure complete with recommendations to the implementation method is comprised in the text book by NACHLIK et. al.: „Identyfikacja i ocena skutków antropogenicznych oddziaływań na zasoby wodne dla wskazania części wód zagrożonych nieosiagnięciem celów środowiskowych" (2004) ["Identification and Assessment of Anthropogenic Pres- 
sure Impacts on Water Resources for the Purpose of Indication to Water Bodies Threatened by Failing to Achieve Environmental Objectives"].

According to the WFD assessment of water status and indication of pressures which may jeopardise achievement of environmental objectives should be done for all water bodies (WB). It should be noted that though the morphological and partly biological status depend on pressures directly connected with the WB, the physicochemical status and the hydrological regime also depend on (point and non-point) pressures connected directly with the WB and upstream WB basins. Due to physical conditions all balancing type analyses (quantity and quality) should be carried out within catchment area boundaries.

Balancing analyses require the use of a number of data on: water resources (volume and quality), water uses, site development and water-wastewater management in the catchment area, water structures, etc. Data on resources are taken from the quantitative and qualitative monitoring network. In Poland, the average density of water mark network is one water mark per about $300 \mathrm{~km}^{2}$ of river basin, in the case of qualitative monitoring network one gauging-control station is located per every $150 \mathrm{~km}^{2}$, where the average surface area of a community is about $125 \mathrm{~km}^{2}$ (in ZGN these indicators are: 480, 160 and $190 \mathrm{~km}^{2}$ respectively). Reliable determination of the quantitative and qualitative water status and indicators related to land and water uses on the grounds of community statistical data requires the use of adequately defined river basin units. Consolidated water bodies comprising catchment areas of one or more surface water bodies are the basic unit, for which assessments of water status and assessments of anthropogenic pressures on that status are made.

\section{UPPER NAREW BASIN}

\section{General characteristics of the Upper Narew basin}

The Narew River is a lowland river, the largest right hand side tributary of the Vistula River, in terms of its basin area $\left(75175 \mathrm{~km}^{2}\right)$. Pilot Upper Narew basin is situated in north-eastern Poland and covers a part of the Narew basin between the State frontier and the mouth of Biebrza (Fig. 2). Its surface area is $7243.5 \mathrm{~km}^{2}$ (including $1159.9 \mathrm{~km}^{2}$ in the territory of Belarus), and the length of the studied river stretch is about $200 \mathrm{~km}$. Mean annual precipitation volume oscillates around 500-600 $\mathrm{mm}$.

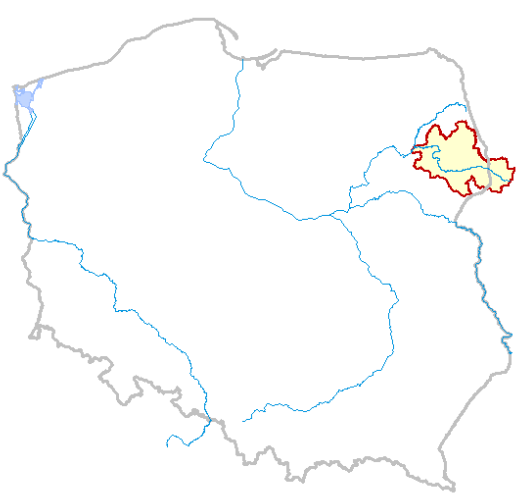

Fig. 2. Location of the Upper Narew basin 
The Narew hydrological regime is featured by occurrence of the highest flows during spring thawing time and low water in summer. The mean multiannual flow over 1976-2002 at the Strękowa Góra, profile, closing the studied district, is $34,2 \mathrm{~m}^{3} \cdot \mathrm{s}^{-1}$. The major tributaries of Upper Narew are: Narewka, Orlanka, Ślina, Supraśl and Nereśl (Fig. 3).

The Upper Narew basin district is situated within the range of two hydrogeological regions: Podlaski and - in the north-eastern part - Suwalsko-Podlaski. Major available groundwater levels occur mostly in Quaternary deposits and only locally - Tertiary deposits. North of Białystok the Main Groundwater Reservoir No 218 has been established - the Pradolina Supraśli, which is used for water supply for the agglomeration of Białystok.

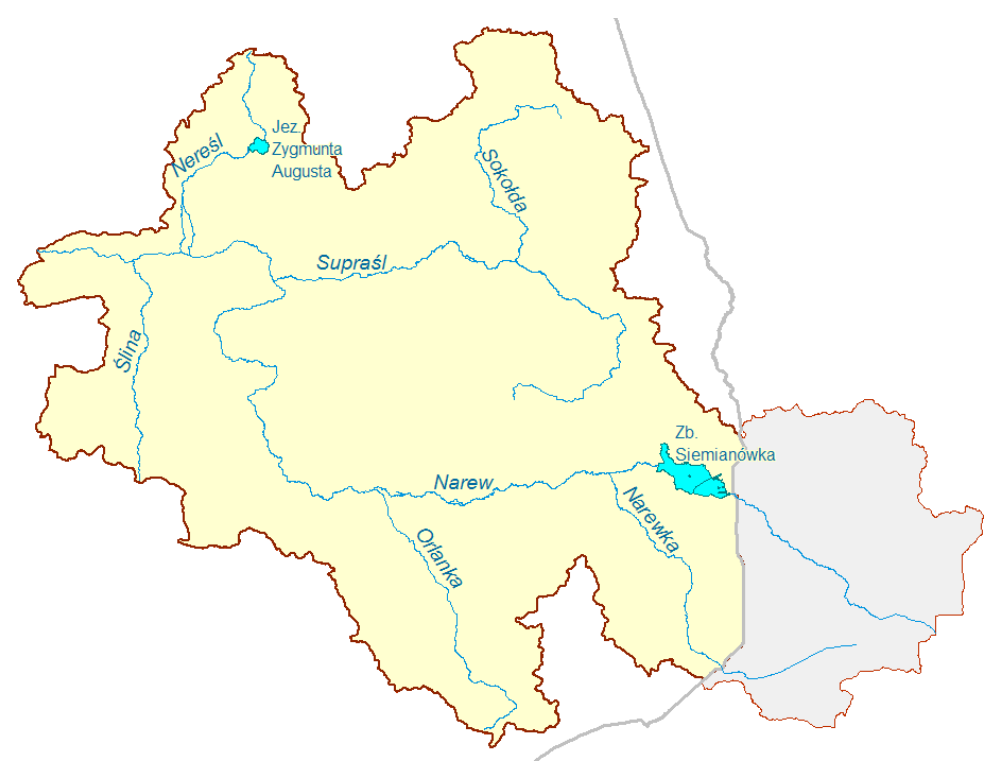

Fig. 3. Upper Narew basin

The Upper Narew basin is totally situated in the territory of the Podlaskie Region, within the area of 7 counties and over 50 communities. Białystok - the capital of the region, is the largest and most important urban centre (about 300 thousand inhabitants). The basin district consists in about 60 per cent of farmland, a major part of that consists of meadows and pastures located in river valleys and land depressions. About 35 per cent of the basin area is covered by forests, located mainly in the northern and eastern part of the basin. Industrial and urban areas occupy a relatively small area (about 5 per cent).

Agriculture is the prevailing branch of economy. Farm animal, particularly cattle, breeding is an important branch of agricultural production. In industry, 
processing and food production prevail. Over 30 per cent of the total basin area is covered by various forms of nature preservation. There are among others two national parks here: Białowieski, established to protect the natural forest complex, a unique one across the European Lowland and Narwiański Park, protecting the natural marshy Narew valley, with strongly developed system of river beds. A large part of the basin, including the larger part of the Narew valley and areas of the Białowieska and Knyszyńska forests, are included into the Natura 2000 programme.

\section{Water bodies in the Upper Narew basin}

Surface waters. Within the framework of the implementation of the first stage of planning work in Poland in the Upper Narew basin 94 water bodies were established for rivers, presenting 5 types, in line with the adopted abiotic typology (including one water body of indefinite type, including the Narew section in the Siemianówka reservoir) and 3 artificial water bodies including water reservoirs (Zygmunta Augusta Lake and the Siemianówka reservoir, divided into two parts). The basin district does not comprise any water bodies of natural lake nature, nor artificial water bodies - canals. One water body has been defined as heavily modified. Surface water bodies are presented in Figure 4.

For the purpose of carrying out the analysis of anthropogenic pressures and their impact assessment, surface water body basins have been delineated and aggregated into the so-called consolidated water bodies. Consolidated water bodies have been established based on: hydrographical conditions, possibility of making reliable assessment of the volume of water resources, their quality status and reliable estimation of indicators related to land use and water uses on the grounds of community statistical data, location of significant users, occurrence of artificial or heavily modified water bodies. As a result, 27 consolidated surface water bodies were established (Fig. 5) in the Upper Narew basin within the borders of Poland. Fig. 6 shows the diagram of interrelations between consolidated water bodies.

Groundwater. The Upper Narew basin has been established as a single body of groundwater (SBG), which may be characterised as a multilayer formation, separated in porous Quaternary deposits.

\section{Data bases on the Upper Narew basin}

The analysis of anthropogenic pressures on waters and assessment of impacts of such pressures requires collection of large volumes of information featuring both the types of human activities in the said area and the current water status. The analysis was done on the grounds of existing data which were collected in the form of numerical data bases. Apart from information about the facility or phenomenon itself, these bases also comprise its location in space, thus allowing cooperation with GIS or they are themselves GIS information horizons. In terms of the subject matter, the data bases which were developed were divided into four groups: 


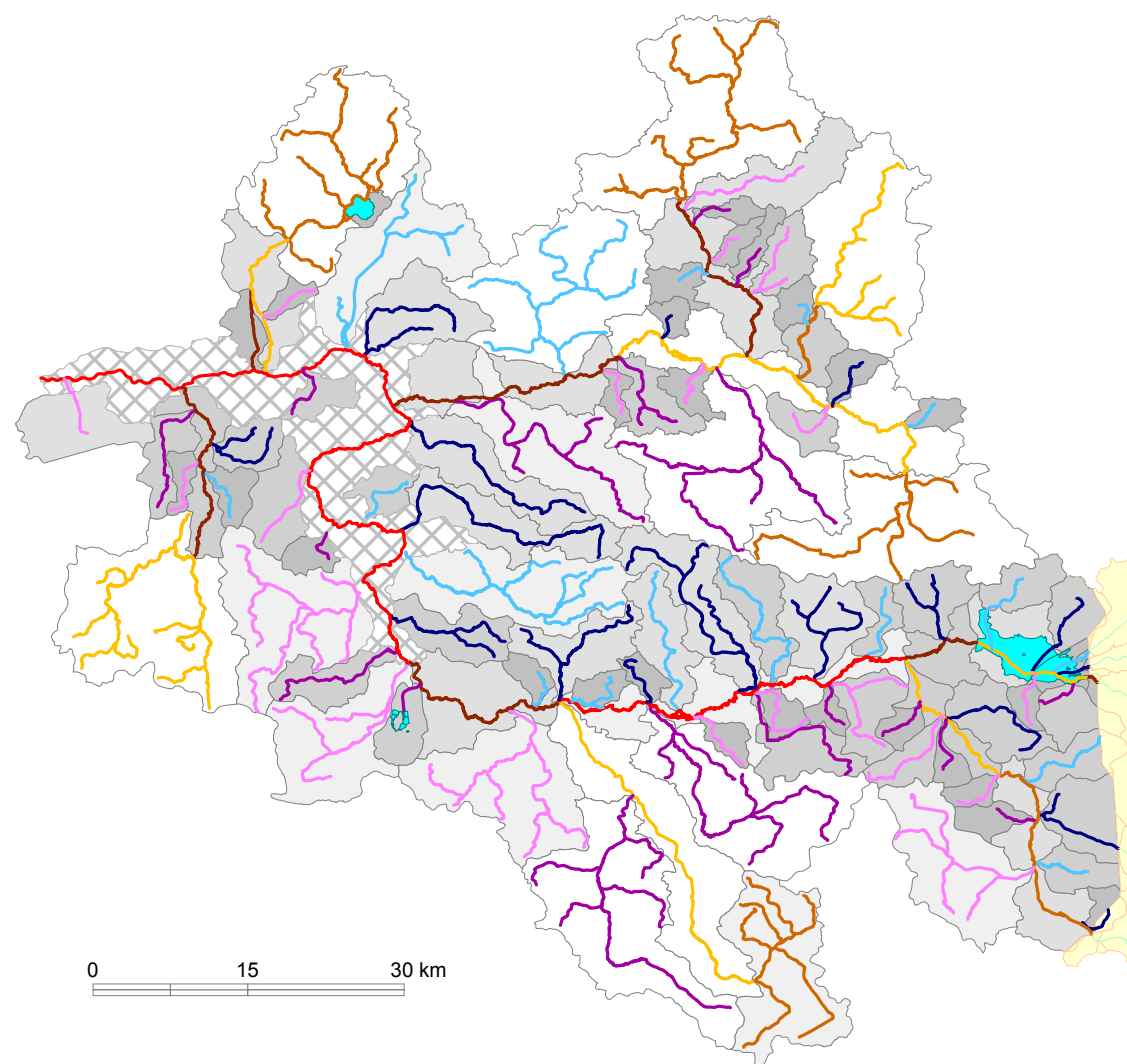

catchment area JCW [km2]

$\square 150$ do 360 (12)

100 do $150 \quad$ (9)

50 do 100 (15)

20 do 50 (28)

0 do 20 (32)

homogenous waters part - rivers

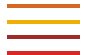

$\overline{=}$

waters artificial part

direct catchment JCW

- Narew from Liza to Biebrza

$8 \times 8$

rivers out of Poland

line

catchments out of Poland

Fig. 4. Surface water bodies (WB) and their basin (colours differentiated to show stretches of water courses which create individual water bodies) 


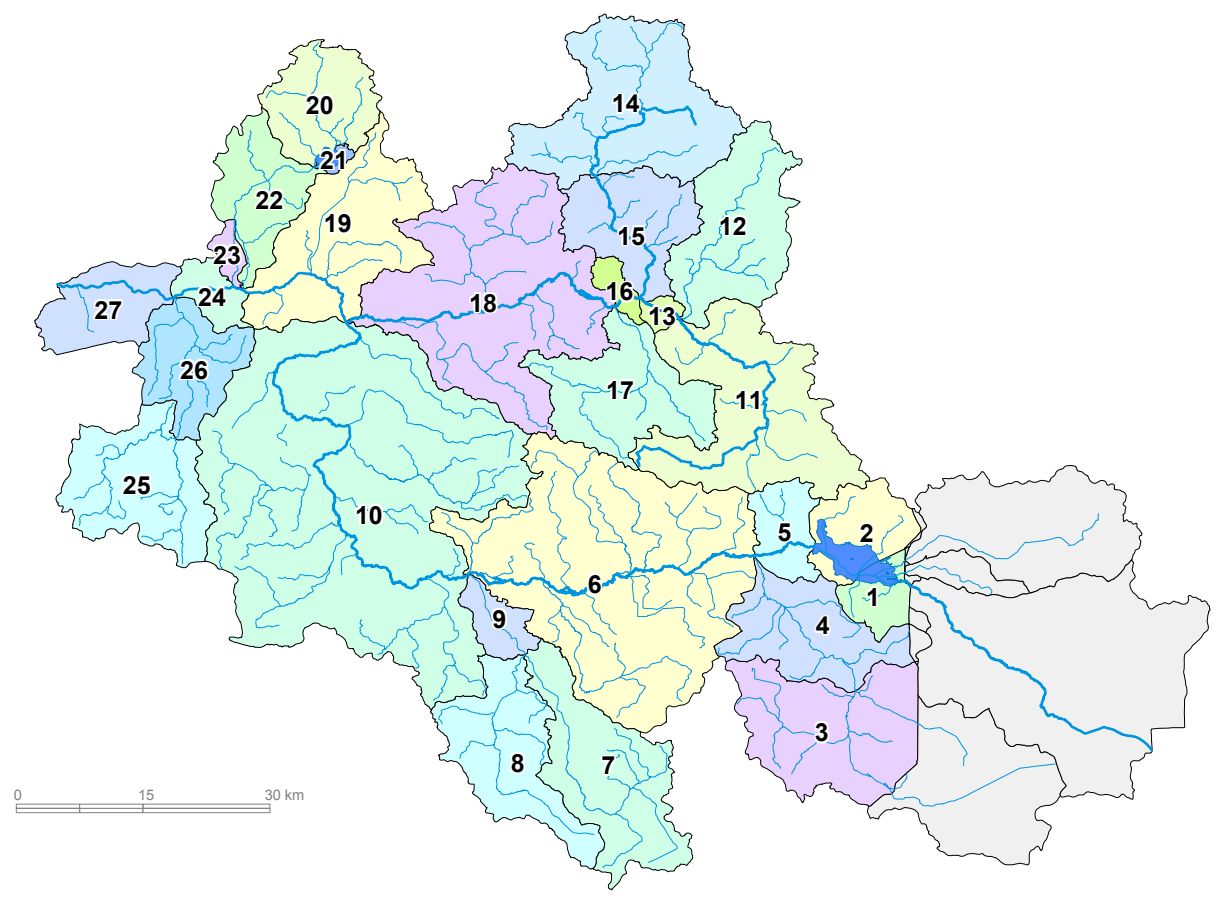

Fig. 5. Consolidated water bodies and their basins

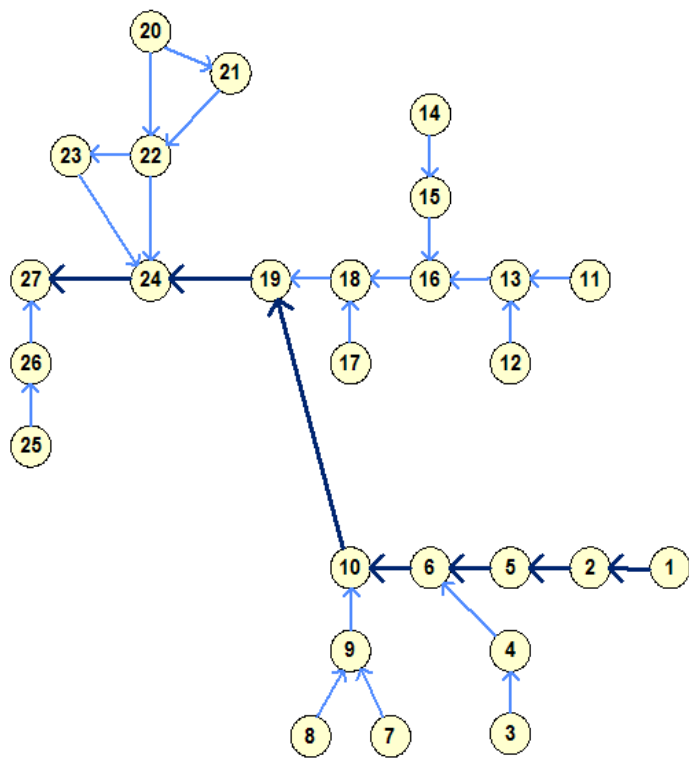

Fig. 6. Diagram of interrelations between consolidated water bodies in the Upper Narew basin 
- data bases on causative factors in communities,

- data bases on anthropogenic pressures,

- data bases on surface water and groundwater status,

- data bases on specific water uses and forms of their protection.

\section{Data base on causative factors}

Analysis of causative factors for consolidated water bodies (CWB) and assessment of the impact of non-point pollution on the quality of surface and groundwaters were done based on statistical data for communities. For all communities within the Upper Narew basin data were collected, featuring the following:

- demographic conditions,

- water-wastewater management,

- industry development,

- agricultural land uses,

- animal breeding,

- level of mineral fertilisation,

- legally protected areas.

For every community within the Upper Narew basin values were determined for 52 indicators featuring various forms of human activities or impacts of such activities.

\section{Data base on anthropogenic pressures}

Data on various types of anthropogenic pressures were divided into 4 groups:

- water intakes for the purposes of: public utilities and industry, irrigation of land reclamation facilities and fish ponds;

- municipal and industrial waste discharges (Fig. 7);

- intensively used small area facilities: areas of agricultural sludge use, large animal breeding centres, areas of intensive pesticide use (e.g. orchards), improved areas, municipal and industrial waste dumping sites in and out of operation, industrial plants essentially affecting the environment with established limited use zone and filling stations;

- water structures: dams of retention reservoirs, storage tanks, drops, weirs and dams, linear structures including elements of longitudinal river bed improvement, dikes and transfer canals.

\section{Data base on the status of surface waters and groundwater}

The water status data base comprises information about the quantitative and qualitative status of surface waters and groundwater. The quantitative status of surface water resources was featured in 15 watermark cross-sections by mean flows $(S S Q)$ and mean low flows $(S N Q)$ for two multiannual periods ("pseudo-natural" 1951-1975, during which the impact of economic activities on water resources was relatively small and the second, comprising the recent years 1977- 


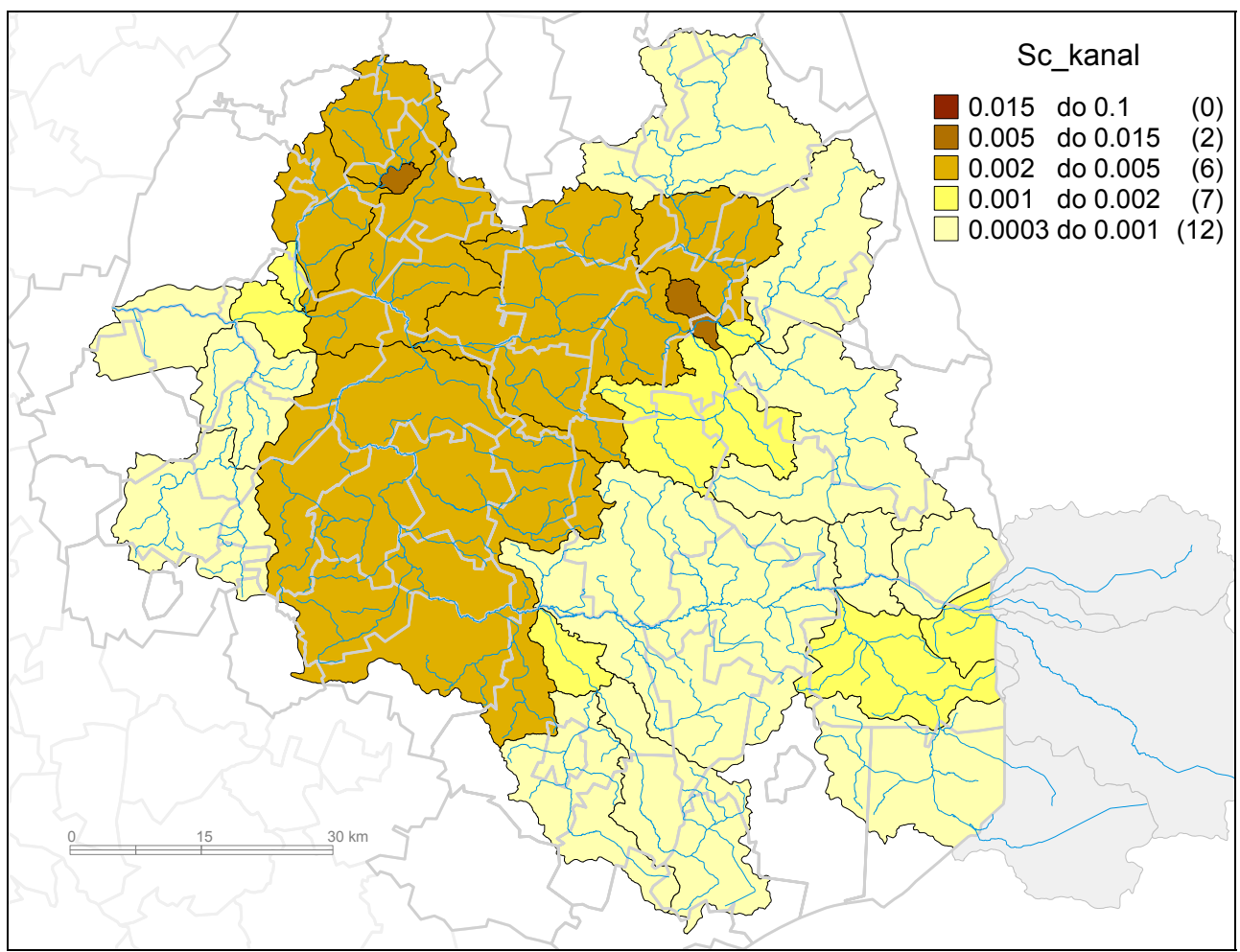

Fig. 7. Distribution of wastewater disposed through the wastewater disposal network $\left(1 \cdot \mathrm{s} \cdot \mathrm{km}^{-2}\right)$

-2002). The qualitative status of surface waters was featured by reliable concentrations (percentile 90) in 48 surface water monitoring stations. Qualitative characteristics comprised 16 major water pollution indicators $(\mathrm{pH}$, conductivity, dissolved oxygen, $\mathrm{BOD}_{5}, \mathrm{COD}-\mathrm{Mn}$, total dissolved substances, ammonium nitrogen, nitrate nitrogen, total nitrogen, phosphates, total phosphorus, copper, zinc, cadmium, mercury, lead) and 4 auxiliary indicators (total suspended solids, chlorophyll "a", saprophytic index, faecal type coli test). The qualitative status of groundwater was featured by 47 pollution indicators in 16 groundwater monitoring wells.

The Institute of Meteorology and Water Management and the Regional Environmental Protection Inspection (WIOŚ) in Białystok were the major providers of information.

\section{Data base on specific water uses and forms of their protection}

Data bases on protected areas in the Upper Narew basin collect information about: 1 water intake for drinking water supply, 13 bathing resorts, $283 \mathrm{~km}$ of rivers earmarked as natural habitats for salmonids and 52 areas under various forms of nature preservation (3 national parks, 2 landscape parks, 39 nature reserves, 
4 protected landscape areas, 8 Natura 2000 areas). In the Upper Narew basin no surface water or groundwater were identified to be sensitive to pollution with nitrogen compounds of agricultural origin (2002 status).

Materials delivered by the Regional Water Management Authority in Warsaw and own materials of the pilot project team were the main source of information.

\section{ANALYSIS OF CAUSATIVE FACTORS}

The causative factor analysis is designed to review the types of human socioeconomic activities in consolidated water body (CWB) basins, which may pose potential threat to water status. Estimation of causative factors for consolidated water body basins was done by way of GIS physical analyses, with the use of statistical data for communities.

Indicators featuring public utilities for consolidated water body basins most often belonged to very low or low class, but reached higher classes in basins comprising larger urban centres (Białystok, Bielsk Podlaski, Łapy, Choroszcz). Indicators featuring agriculture and forestry reached average class values more often (average and higher classes positively prevail for farm animal breeding, average class most often occurs for the indicator for water intake for the needs of agriculture and forestry). Indicators featuring industry primarily fall into very low classes, exclusive of consolidated water body basins comprising Białystok and Bielsk Podlaski. Figure 7 presents for example the distribution of wastewater disposed through the wastewater disposal network in Upper Narew consolidated water body basins.

\section{IDENTIFICATION AND ASSESSMENT OF THE CURRENT STATUS OF CONSOLIDATED WATER BODIES IN THE UPPER NAREW BASIN}

Identification and assessment of the surface waters and groundwater status is based on the results of monitoring research for the year proceeding the year of the task execution, collected in data bases. Identification and assessment of the current water status is a stage of planning work, including:

- assignment of numerical values of water status indicators to individual water bodies based on monitoring results and collected data (status identification);

- definition of threshold values of good water status indicators with consideration for requirements resulting from their specific uses;

- comparison of indicator values featuring the status of the studied water body with threshold values of good status and evaluation of status;

- distinguishing consolidated and single water bodies which meet the good status requirements and are not threatened with the risk of failing to achieve the environmental objectives by 2015; during the consecutive stages of the planning cy- 
cle - following the development of the socio-economic development forecast and the water status forecast - this evaluation shall undergo verification;

- identification of water bodies which do not meet the good water status requirements or which are insufficiently recognised to enable evaluation of their status for the purpose of exposing them to detailed analysis for verification of the risk of failing to achieve good status and identification of the reasons;

- assessment of the gap between water status and the good status requirements which are the grounds for definition of the type and scope of measures requires to improve the water status.

It should be noted that although, under the provisions of the WFD, the status of surface waters should be assessed primarily on the grounds of biological quality elements, in view of the lack of monitoring data which could provide biological indicators, assessment of the current water status is based on available indirect indicators (hydromorphological, physico-chemical and - to a very limited extent biological).

It was assumed that in the first planning cycle such tasks as: water status assessment, gap analysis, determination of the programme of measures focused on achieving good water status, shall be developed based on the results of the existing monitoring, having in mind its limited range. Verification of adopted approaches and their possible correction shall be possible as late as 2008 , with availability of results of the WFD required monitoring system (surveillance, operational and investigative), the programmes for which Member States should develop by the end of 2006.

Within the KBN grant "Methodological Foundations for the National Plan for Integrated Water Management Development in Poland", work headed by Prof. E. Nachlik, the expert team proposed a list of physico-chemical, biological, hydrological and morphological quality indicators (elements) for description of water status in Poland in the first WFD planning cycle. A good water status threshold value was determined for each of the proposed indicators. In respect of the hydrological and morphological quality indicators also definitions and calculating method were provided. The proposed indicator threshold values, designating good water status, go along with the formerly used systems of water quality classification and incorporate forms of protection associated with drinking water intakes, bathing resorts and fish living in natural conditions.

\section{Identification and assessment of surface water status}

Comprehensive (general) assessment of the status of consolidated surface water bodies was based on independent assessments of physico-chemical and biological status and the hydromorphological status. The general assessment was the worse of combined assessments. Combined assessments in hydromorphological and physico-chemical with biological indicator groups were made on the following principles: 
- the physico-chemical and biological status is considered at least good, where one at the most major indicator and/or not more than two auxiliary indicators exceed the threshold values, fixed in view of specific uses of water;

- the hydrological and morphological status is considered at least good if none of the indicators exceed the threshold values;

- in cases where the thresholds were exceeded negligibly and where reliability of the results of identification of CWB was limited, possibility of expert settlements was admitted.

As a result of expert assessment the physico-chemical status of two CWB was changed from fair to good, due to slight excess of indicator threshold values. Also the low level of representativeness of monitoring stations for certain consolidated water bodies was also taken into account.

Identification and assessment of the current water status in respect of hydrological and morphological indicators of consolidated surface water bodies (rivers) covered the following issues:

- selection of representative watermark cross-sections for CWB;

- transfer of information on characteristic flows $(S N Q, S S Q)$ from watermark cross-sections to the CWB closing cross-section;

- calculation of hydrological status indicator values based on data on characteristic flows, water uses and water structures;

- designation of essential water courses for assessment of morphological status and determination of their characteristics;

- calculation of morphological status indicator values based on data of location and parameters of water structures;

- comparison of the computed values of indicators of hydrological and morphological status with good status threshold values.

For the purposes of combined assessment of hydromorphological status a twoscore scale was used - good status (none of the indicators exceed threshold values) or bad (at least one indicator exceeds the values set).

Similarly to the physico-chemical water status, expert verification was made for the assessment of hydromorphological status, upon the following premises:

- the size of irrigated areas (taken into account in defining the non-returnable intakes) is overestimated; inventories were made on reclaimed land, where the state of repair allows irrigations. Data provided by WZMiUW in Białystok show, that over the recent years irrigated areas are being considerably reduced;

- indicator of change in the hydrological regime due to different "water volume" in multiannual periods of 1951-1976 and 1977-2002 and incomplete hydrological data (shorter series at certain watermarks) should be used as supplementary;

- occurrence of a large number of low dams and weirs results in overestimation of the damming height indicator. 
Verified results of the assessment of hydromorphological status for individual CWB are presented in Figure 8.

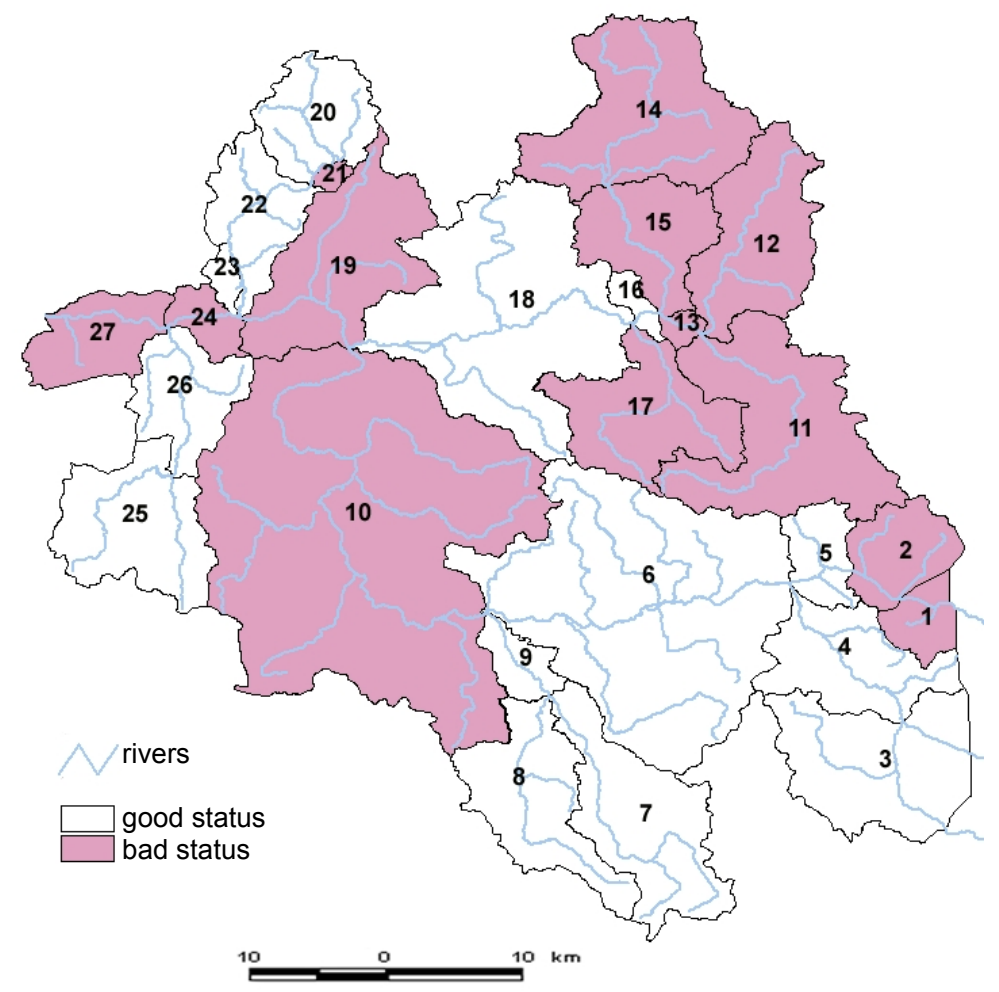

Fig. 8. Combined assessment of hydromorphological status of CWB

The results of assessment of hydromorphological and physico-chemical with biological status and analysis of causative factors are summarised in the form of two tables for each consolidated water body.

General assessment of the CWB was made based on the results of the assessment of the physio-chemical with biological and hydromorphological status on the principle that the general assessment depends on the lower of the two partial analyses. Based on the assessment of water status a draft list of CWB threatened (general assessment below good status) and potentially threatened (lack of data or data unreliable) by failing to achieve good status. A detailed analysis of pressures and/or (additional) monitoring tests are required for all the $13 \mathrm{CWB}$ comprised on that list.

\section{Remarks on the assessment of surface water status}

Assessment of the current status of consolidated water bodies in the Upper Narew basin was based on indirect indicators - hydromorphological, physico- 
chemical and biological, though the latter to a limited extent. The set of indicators and their threshold values used for assessment of water status for CWB is at the moment a proposal of indirect indicators for assessment and indirect environmental objectives. The use of these (or other) indicators and threshold values in further planning work depends on adoption of arrangements binding across the country. It should be noted that the proposed list of indicators and their good status threshold values should be made more detailed - i.a. through diversification of the threshold values for physico-chemical indicators depending on abiotic typology of waters, supplementation of indicators for selected priority substances, fixing more accurate hydromorphological indicators. Experience acquired in pilot basins (Raba, Upper Wisła, Upper Narew) may be helpful in establishment of the indirect water status assessment system.

Although the WFD recommends development of assessments of water status on the grounds of biological indicators, at the present stage status assessment must be done based on available indirect indicators. Once the results of monitoring of biological quality indicators are available, they will be used for verification of assessments done with the use of those indicators. Indirect indicators shall also be used for development of water status forecast for 2015, accounting for the anticipated socio-economic development (and the resulting changes in anthropogenic pressures) and effects of measures undertaken to protect and improve the water status. It should be noted that for a long time yet the level of expertise will not allow reliable forecasting of behaviour of ecosystems or specific parts of such systems, in response to specific anthropogenic pressures or measures reducing the impact of such pressures. Thus it will be necessary to use indirect water status indicators (complete with indirect environmental objectives in form of good status threshold values) also in later stages and planning cycles.

\section{Assessment of the quantitative and qualitative status of groundwater}

Assessment of the quantitative and qualitative status of groundwater was done by comparison of the groundwater intake module with the available resource module. The quantitative status of groundwater was determined on the grounds of the following criteria:

$$
\begin{aligned}
& \mathrm{M}_{\text {Qintake }} \leq 0.75 \mathrm{M}_{\text {Qavail. }} \quad \text { - good status } \\
& 0.75 \mathrm{M}_{\text {Qavail. }}<\mathrm{M}_{\text {Qintake }} \leq \mathrm{M}_{\text {Qavail. }} \quad-\text { fair status } \\
& \mathrm{M}_{\text {Qintake }}>\mathrm{M}_{\text {Qavail. }} \quad \text { bad status }
\end{aligned}
$$

Computed modules for the Upper Narew basin are as follows:

$$
\begin{aligned}
& \mathrm{M}_{\text {Qintake }}=17.5 \mathrm{~m}^{3} \cdot 24 \mathrm{~h} \cdot \mathrm{km}^{-2} \\
& \mathrm{M}_{\text {Qavail. }}=81 \mathrm{~m}^{3} \cdot 24 \mathrm{~h} \cdot \mathrm{km}^{-2}
\end{aligned}
$$

Based on comparison of available resource module and the mean annual intake module, the quantitative status of groundwater in the Upper Narew basin was assessed as good status. 
Assessment of the qualitative status was done on the grounds of comparison of representative values of physico-chemical parameters, obtained from groundwater quality monitoring stations with threshold values for those parameters. Analysis of data from the groundwater quality monitoring system shows that water in the Upper Narew basin district is featured by good physico-chemical status. There are spots where the status is slightly worse, but no basin districts were found with bad status of groundwater. No effects of salinity e.g. from inflow of highly mineralised water from deeper aquifers were observed. However, the areas of Białystok and Suraża agglomerations are threatened by degradation of groundwater quality. It is necessary to establish groundwater quality monitoring in those areas.

\section{SUMMARY}

The Summary comprises the most significant problems, discussed in the paper: "G3 Guidelines - Planning Water Management in Poland under the Provisions of the Water Framework Directive" and "Identification of Anthropogenic Pressures on Waters and Assessment of their Impacts on the Example of Upper Narew Ba$\sin "$.

The key objective of Guidelines G3 consisted in discussion of the process and methodological assumptions for development of river basin management plans as laid down by the EU Water Framework Directive, with particular consideration for Polish experience and legal regulations.

Analysis of the national and regional plans shows that the current year, 2006, shall determine the key lines of national and regional development practically till 2015, that means till the time when, under the Water Framework Directive, Poland should have achieved its major objectives. This year shall witness decision making not only on the key objectives, priority strategies and measures undertaken for social and economic development of the country and regions, but also allocation of the main streams of funds from the EU and public funds from national sources. This is a sort of challenge for administration bodies responsible for water management, particularly in respect of programming water management tasks and their incorporation into documents which are strategic for development on national and regional level. Over 2006-2008 efforts of water management administration bodies should be focused on incorporation of water management issues into the consecutive edition of the National Ecological Policy and environmental protection programmes - at regional level, to be followed by county and community levels.

The "Guidelines..." pay particular attention to components 4 and 5, comprising gap analysis and determination of programmes of measures. They are of key importance to the whole process of preparing river basin management plans. The Guidelines present a proposal of a method for gap analysis and discuss the key assumptions for that analysis: geographical range of analysis and the use of indirect 
objectives. It was proposed that planning documents for basin districts (River Basin Management Plan and the National Water-Environmental Plan) be developed as a synthesis of documents developed in water regions or smaller areas units. It was recommended that water regions be split into balancing districts (basins) for the needs of all analytical work (balances, proposals for programmes of measures, economic analyses, etc.).

Handbook "Identification and Assessment of Anthropogenic Pressure Impacts on Water Resources for the Purpose of Indication to Water Bodies Threatened by Failing to Achieve Environmental Objectives" (NACHLIK et al., 2004) presents a consistent, practical procedure for identification of threats and assessment of water status. It defines the scope of data required for the analysis, indicators which are the basis for determination of water status and threshold values for good status, allowing its assessment. Feasibility of this methodology was tested in the pilot Upper Narew basin.

It seems worthy to pay particular attention to the proposed system of indirect water status assessment, based on expert defined threshold values for physicochemical, biological, hydrological and morphological indicators. This is particularly important in view of the fact that at present it is impossible to assess water status on the grounds of biological quality elements. It was also pointed out that indicator threshold values should be adjusted to distinguished types of surface waters.

A number of problems with application of hydromorphological indicators were pointed out. These indicators are described in the methodology "Identification..." (NACHLIK et al., 2004). Modification of definitions and computation methods were proposed for some of them.

It was also stated during the work for the Upper Narew basin that the currently existing network of monitoring stations does not allow the preparation of a reliable assessment of consolidated surface water bodies. It will be necessary to adjust the monitoring network to the boundaries of consolidated water bodies alongside development of the water monitoring programmes.

Assessment of water status and identification of significant anthropogenic pressures were preceded by a number of inventory tasks and development of data bases describing the water status, forms of specific water uses and protected areas, anthropogenic pressures on water and factors featuring socio-economic conditions. Development of data bases was the most laborious stage of work in the pilot basin. The huge amount of work on development of data bases resulted from the fact that essential data were dispersed among a number of institutions which collected those data, none of the data were in digital format, particularly in respect of spatial location, or they were saved in incompatible systems.

Inconsistency of data originating from various sources was a substantial problem faced during work in the pilot basin. Such inconsistencies deteriorate reliability 
of analyses and may have an adverse impact on the quality of future planning work. Reconstruction of the system for collecting data on natural environment and making them available and (the soonest possible) launching the water register may considerably contribute to improve future planning work and to enhance reliability of the results of analyses done.

Identification of significant anthropogenic pressures and assessment of water status were carried out for consolidated surface water bodies, which consisted of one or several water bodies. It should be noted, however, that in the case of morphological transformations it will be necessary to analyse individual water bodies and the assessment done for the consolidated water bodies may be looked upon as a preliminary stage, in which consolidated water bodies, which require detailed studies, were identified.

To summarise the implementation work one can say that analyses for the Upper Narew basin, done in consistence with recommendations of the "Identification and assessment..." (2004) handbook provided a basis for a review of essential problems in water management in this district.

\section{REFERENCES}

1. Directive 2000/60/ec of the European Parliament and of the Council of 23 October, 2000 establishing a framework for community action in the field of water policy. Ministry of Environment materials (http://www.mos.gov.pl/dzw/dokumenty/ ramowa_dyrektywa_wodna.doc).

2. NACHLIK E. et al., 2004. Identification and assessment of anthropogenic pressure impacts on water resources for the purpose of indication to water bodies threatened by failing to achieve environmental objectives. Cracow, Publishing House of the Cracow Technical University.

3. Typology of surface waters and Identification of surface water and groundwater bodies under the Provisions of the WFD 2000/60/EC; 2004. Consortium: Institute of Meteorology and Water Management, Institute of Environmental Protection, National Institute of Geology, Maritime Institute.

4. G3 Guidelines - Planning water management in Poland under the provisions of the Water Framework Directive, 2005. Technical Assistance in the Implementation of WFD 2000/60/EC in Poland. Warszawa.

5. PusŁowsKA-TYSZEWSKA et al., 2005. Identification of anthropogenic pressures on waters and assessment of their impacts on the example of Upper Narew Basin. Warsaw, Publishing House of the Institute of Environmental Engineering Systems of the Warsaw Technical University.

6. General agricultural census 2002, 2003. Warszawa, GUS (http://www.stat.gov.pl)

7. Statistical year book - environmental protection, 2003. Warszawa, GUS.

8. Environment status in the Podlaskie Region over 2000-2001, 2002. Environment Monitoring Library. Białystok, WIOŚ.

9. Tender dossier for the unlimited tender procedure for "Development of analysis of pressures and impacts of anthropogenic pollution in detailed breakdown to surface water and groundwater bodies for the purpose of development of programmes of measures and water management plans", 2006. Warszawa, National Fund for Environmental Protection and Water Management. 


\section{STRESZCZENIE}

\section{Elementy procesu planowania gospodarowania zasobami wodnymi według Ramowej Dyrektywy Wodnej na przykładzie górnej Narwi}

Słowa kluczowe: bilans wodny, gospodarka wodna, hydrologia, plan ochrony, zlewnia rzeczna

Omówiono najważniejsze własności i etapy procesu planowania gospodarowania wodami w obszarach dorzeczy, zgodnie z zaleceniami Ramowej Dyrektywy Wodnej UE. Przedstawiono metodycznie jeden z najważniejszych etapów procesu planowania, jakim jest identyfikacja antropogenicznych oddziaływań na wody i ocena ich skutków. Identyfikacja ta stanowi element zarówno wstępnej, jak i właściwej analizy problemów gospodarki wodnej w obszarze dorzecza i jest podstawą do realizacji kolejnych etapów cyklu planistycznego, zwłaszcza opracowywania planów gospodarowania wodami na obszarach dorzeczy wraz z programami działań niezbędnych do osiagnięcia celów środowiskowych RDW. Opisano kolejne etapy prac i doświadczenia autorów uzyskane w wyniku wdrożenia tej metodyki w zlewni pilotowej górnej Narwi. Prace w tej zlewni nie objęły jeszcze prognozy stanu wód w roku 2015 ani analiz zmierzających do określenia niezbędnych dla osiagnnięcia dobrego stanu wód w 2015 r.

Reviewers:

Prof. Waldemar Mioduszewski

Prof. Czesław Przybyta 